\title{
Analysis of the Sustainability Status of Feed Banks in the 1000 Village Cow Program in Pujut District, Central Lombok: (Dimension of Availability, Human Resources Management, and Production System, Price, Feed Distribution)
}

\author{
${ }^{1}$ Mashur, ${ }^{2}$ Subagio, ${ }^{3}$ Kemas Usman, ${ }^{2 *}$ Hunaepi \\ ${ }^{1}$ Feed Department, Nutrition and Social Economy, Universitas Pendidikan Mandalika, Jl. \\ Pemuda No. 59A, Mataram, 83125, Indonesia \\ ${ }^{2}$ Biology Education Department, Universitas Pendidikan Mandalika, Jl. Pemuda No. 59A, \\ Mataram, 83125, Indonesia \\ ${ }^{3}$ Forestry Department, Universitas Pendidikan Mandalika, Jl. Pemuda No. 59A, Mataram, \\ 83125, Indonesia \\ *Corresponding Author e-mail: hunaepi@undikma.ac.id
}

Received: November 2021; Revised: December 2021; Published: December 2021

\begin{abstract}
West Nusa Tenggara Province is one of the centers for beef cattle production in Indonesia, which was set by the Ministry of Agriculture as a pilot program for the 1000 village cattle program in realizing national beef selfsufficiency. The supporting factor for the success of the 1000 village cattle program is the provision of feed throughout the year. The existence of a feed bank is expected to be a solution to overcome the limited supply of feed, especially in the dry season. The Bumbang Wetan Feed Bank in Mertak Village is a feed bank that is expected to supply animal feed needs in five pilot villages of the 1000 village cattle program in Pujut District, Central Lombok Regency. To determine the sustainability status of the feed bank in supporting the 1000 village cattle program, a study was carried out in June-August 2021. The determination of the sustainability status of the feed bank was based on the sensitive attributes of the three dimensions studied, namely: (1) availability of feed ingredients; (2) production, pricing, and distribution systems; (3) human resources management. These attributes are arranged referring to the results of primary data collection using a questionnaire. The research method used is descriptive qualitative. Determination of the sustainability status of the feed bank is carried out using the Multi-Dimensional Scaling method with the Rapid Appraisal Beef Cattle Feed Bank Smallholder approach. The results showed that the sustainability value of the three dimensions was 50.59 , so it was concluded that the status of the feed bank was in the less sustainable category in supporting the 1000 village cattle program.
\end{abstract}

Keywords: Feed Bank, Sustainability Status, 1000 Cow Villages

How to Cite: Mashur, M., Subagio, S., Usman, K., \& Hunaepi, H. (2021). Analysis of the Sustainability Status of Feed Banks in the 1000 Village Cow Program in Pujut District, Central Lombok: (Dimension of Availability, HR Management, and Production System, Price, Feed Distribution). Prisma Sains : Jurnal Pengkajian Ilmu dan Pembelajaran Matematika dan IPA IKIP Mataram, 9(2), 365-377. doi:https://doi.org/10.33394/j-ps.v9i2.4347

https://doi.org/10.33394/j-ps.v9i2.4347

\section{INTRODUCTION}

West Nusa Tenggara Province is one of the five beef cattle production centers in Indonesia, which was determined by the Directorate General of Livestock and Animal Health, Ministry of Agriculture of the Republic of Indonesia, as a pilot development of 1000 beef villages in Indonesia in order to support the national beef self-sufficiency program materialized so far. There are five villages in Pujut District, Central Lombok Regency, West Nusa Tenggara Province that have been designated as pilot villages for the implementation of the $1000 \mathrm{cow}$ village program in 2020, namely Mertak, Sukadana, Teruwai, Pengngat, and 
Bangket Park villages. The five villages were chosen because they are close together, making it easier to develop, assist and supervise livestock groups, either by inseminators, veterinarians, agricultural extension workers, and other officers in the field. The Minister of Agriculture of the Republic of Indonesia hopes that through the pilot program of 1000 cattle villages, the province of West Nusa Tenggara can become a locomotive for the implementation of the development of Indonesian beef cattle. For this reason, beef cattle farms in West Nusa Tenggara must move faster in supporting the national beef supply independently (Herman, 2020).

One of the main factors that are very important to support the success of the 1000 village cattle program in addition to providing seeds and good management is the provision of adequate animal feed both in quantity and quality throughout the year. The existence of a feed bank is expected to be a solution to overcome this problem. In addition to being designated as one of 1000 cattle villages, Mertak Village was also selected as a feed bank village to support the provision of animal feed for four other villages, so that the existence of a feed bank is expected to help overcome difficulties in providing animal feed, especially during the dry season. This is in accordance with the results of Mashur's research (2017), the availability of animal feed, especially during the dry season, is a major problem for beef cattle farmers on smallholder farms in West Nusa Tenggara in facing the MEA (Mashur, 2017).

The Bumbang Wetan Feed Bank in Batu Guling Hamlet, Mertak Village, was inaugurated in November 2021 by the Director-General of Livestock and Animal Welfare of the Indonesian Ministry of Agriculture, represented by the Director of Feed together with the Governor of NTB. The feed bank is equipped with a chopper with a production capacity of 6 tons/day and a trailer for packing feed-in preserved form (silage) with standardized silage baller products. If these feed bank tools and machines can operate optimally, the feed requirement for 1000 head of cattle in five villages in Pujut District is sufficient to help provide animal feed, especially during the dry season. The first production target of the Bumbang Wetan Feed Bank is 85 tons to be distributed to cattle groups in the 1000 village cattle program in five villages in Pujut District. The five villages receiving the 1000 village cattle program are each required to have 40 ha of forage source land. Forage production from five villages is then sent to the Bumbang Wetan Feed Bank to be processed and prepared in the form of silage baller to be stored as feed reserves during the dry season.

Based on the results of monitoring the implementation of the Bumbang Wetan Feed Bank management until March 2021, there are several problems that can be identified, including: (1) The Bumbang Wetan Feed Bank has not carried out the production process again since it was launched in November 2020, because the raw materials for feed mixing are not yet fully available. ; (2) The existing feed products in the form of silage baller in the first production have not been taken by farmer groups from four villages in the 1000 village cow program so that some have started to rot; (3) The organization for managing the feed bank has been formed but the implementation of the main tasks and functions of each has not been running as expected; (4) The management of the feed bank feels the need for a special companion in the management of the feed bank; (5) The level of knowledge and skills of feed bank managers is still very limited in terms of management, technology, product distribution, transportation systems for feed raw materials; (6) The price of silage baller feed products is felt to be still expensive Rp. $1500 / \mathrm{kg}$ so it is not affordable by the purchasing power of farmers.

Based on these matters, efforts are needed in an integrated, integrated, coordinated, and planned manner so that the existence of the Bumbang Wetan Feed Bank can run optimally and independently. If the management of the feed bank does not run well and the feed processing machine tools cannot operate optimally, then the operating costs of the machine tools are not proportional to the income. This can cause the management of the feed bank to lose money, there will be no maintenance costs and eventually, the machine tool will 
stop being used, so that it becomes a threat to become scrap metal. For this reason, as a basis for taking responsive and anticipatory policies on the sustainability of feed banks, a study has been carried out to determine the sustainability status of feed banks in supporting the 1000 village cattle program in five villages in Pujut District, Central Lombok Regency.

Research aims; 1) explore information about the sustainability status of the feed bank from the three dimensions studied and it can be seen which attributes of each dimension are the most sensitive that affect the sustainability of the Bumbang Wetan Feed Bank in supporting the provision of feed in the 1000 village cattle program in Pujut District, Central Lombok Regency, and 2) Multidimensional System (MDS) analysis to determine the sustainability status of each dimension that can be used as a basis for determining a feed bank development strategy that supports the 1000 cattle village program in West Nusa Tenggara.

\section{METHOD}

There are six stages of research that have been carried out to analyze the sustainability status of the beef cattle feed bank in the 1000 village cattle program on community farms based on collective cages in Pujut District, Central Lombok Regency as follows:

1. Determination of the sustainability attributes of the feed bank and its development in the 1000 village cattle program. Determination of the sustainability attributes of beef cattle feeds banks on smallholder farms in five villages where the program is located for 1000 cattle villages in Pujut District, Central Lombok, based on 3 (three) approaches to sustainability dimensions, namely: (1) the dimensions of the availability of feed raw materials; (2) the dimensions of the production system, price and distribution of products; and (3) the dimensions of human resource management and breeders. Attributes are arranged referring to the results of primary data collection conducted using a questionnaire. Expert opinions from practitioners and academics are also considered in the preparation of attributes;

2. Assessment of attributes in the sustainability scale of each dimension. Attribute assessment and scoring based on research, field observations, and available secondary data. Each attribute is assigned a score that reflects the sustainability of each dimension. The score ranges from 1-5 based on the Linkert scale (George \& Mallery, 2014) depending on the individual circumstances. A bad score $=1$ reflects the most unfavorable condition for the development of a beef cattle feed bank on community farms based on collective stables on a sustainable basis, on the other hand, a good score $=5$ reflects the most favorable condition for the development of a beef cattle feed bank on a community farm based on a collective cage;

3. Compilation of a sustainability index for the development of a feed bank in the 1000 village cattle program. The preparation of the sustainability index scale for the development of feed banks in the 1000 village cattle program on smallholder beef cattle farms based on collective cages has an interval of 0-100. If the system under study has an index of $>50$ then the system is categorized as sustainable, and vice versa if the value is < 50 , then the system is categorized as unsustainable. The category of sustainability status of feed bank development on beef cattle farms based on collective cages is organized into four categories (Susilo, 2016). In this study, four categories of sustainability status were arranged based on a basic scale (0-100) as presented in Table 2.

Table 2. Categories of feed bank sustainability status in the 1000 village cattle program in Pujut District, Central Lombok Regency in 2021

\begin{tabular}{cc}
\hline Index & Category \\
\hline$<25$ & Bad \\
$25-50$ & Not enough \\
$51-75$ & Enough \\
$>75$ & Well \\
\hline
\end{tabular}


4. Stages of coordination. The ordination stages were analyzed by MDS to determine the position of the good (good) and bad (bad) points. Objects or points in the MDS will be mapped into three-dimensional space and sought to be as close as possible. According to (Fauzi \& Suzy Anna, 2005) this ordination process aims to determine the distance in the MDS based on Euclidian distance. The position of the bad and good points is depicted horizontally, while the vertical shows the difference in the combination of the assessed attribute scores. (Susilo, 2016) said that the position of the point would be very difficult to imagine if the dimensions studied were many, to make it easier to visualize the position of the point, MDS analysis was used;

5. Leverage Analysis. Leverage analysis was carried out to see the most sensitive attributes that contributed to the sustainable value of the development of smallholder beef cattle farms based on collective cage health management. The effect of each attribute is seen in the form of changes in Root Mean Square (RMS). If the RMS value is greater, then the attribute is more sensitive in supporting the sustainability of feed bank development in the 1000 village beef cattle program based on collective cages

6. Monte Carlo analysis. Monte Carlo analysis is a statistical simulation method for evaluating the effects of errors or the effects of errors on statistical processes. The point evaluated in this study is the ordinance point. The results of the Monte Carlo analysis in this study were presented in the form of a scatter plot with 25 replications. According to (Kavanagh \& Pitcher, 2004) Monte Carlo analysis is useful for studying: (a) The effect of attribute scoring errors caused by lack of information, misunderstood attributes or how to make attribute scores; (b) The effect of variations in scoring due to differences in opinions or judgments by different researchers; (c) Stability of repeated MDS analysis process (unstable anchor position); (d) Errors in data entry or missing data (missing data) and (e) The high value of "stress" analysis results

Research has been carried out at the Bumbang Wetan Feed Bank in Batu Guling Hamlet Mertak village and five farmer groups implementing the 1000 cattle village program in five pilot villages of the 1000 cattle village program in Pujut District, Central Lombok Regency, namely Mekar Jati farmer group in Mertak village, Tunas Karya II farmer group in Teruwai village, Mele Maju farmer group in Sukadana village, Dui Urip farmer group Bangket Parak Village and Tandur Desi Farmer Group Pengngat Village for three months, starting June-August 2021.

The variable to be measured is the Sustainability Index of the People's Livestock Beef Cattle Feed Bank (ikb-BCFBS). The sustainability index value of each dimension can be visualized in the form of a kite diagram. The research method used is descriptive qualitative and quantitative. Determination of the sustainability status and development strategy of the Feed Bank is carried out using the Multi-Dimensional Scaling (MDS) method with the Rapid Appraisal Beef Cattle Feed Bank Smallholder (RAP-BCFBS) approach. This method is a development and modification of the Rapfish approach used to assess the sustainability status of capture fisheries (Kavanagh, 2011), Rap-Agrosapot which is used to assess the sustainability status of Beef Cattle Farming Areas for Agropolitan Area Development in Bondowoso Regency (Ramadhan et al., 2014; Suyitman et al., 2012), Rapseaweed which is used in the Sustainability Analysis of Seaweed-Based Coastal Area Development in West Sumbawa Regency (Nuryadin, 2015) and RAP-BCS which is used to determine the sustainability status and development of beef cattle based on collective cages on smallholder farms. on the island of Lombok (Mashur et al., 2020).

The score value of each attribute is analyzed multi-dimensionally to determine one or several points that reflect the position of the feed bank sustainability against two reference points, namely the good point and the bad point. Through the MDS method, the position of the sustainability point can be visualized through the horizontal and vertical axes. With the rotation process, the position of the point can be visualized on the horizontal axis with the sustainability index value given a score of $0 \%$ (bad) and $100 \%$ (good). If the system under 
study has a sustainability index value of $50 \%$, the system is said to be sustainable and unsustainable if the index value is $<50 \%$ ). The results of the sustainability analysis are stated in the Sustainability Index of the People's Livestock Beef Cattle Feed Bank (ikb-BCFBS). The sustainability index value of each dimension can be visualized in the form of a kite diagram. The formulation of a feed bank development strategy to support the 1000 cattle village program is based on the sensitive attributes of the leverage analysis using RAPBCFBS (Rapid Appraisal Beef Cattle Feed Bank Smallholder) on each sustainability dimension. The most dominant sensitive attribute will be carried out by various efforts or improvement strategies without reducing other attributes

The types of data needed in the research on sustainability analysis of the feed bank and its development strategy in supporting the 1000 village cattle program in five villages in Pujut District, Central Lombok Regency, West Nusa Tenggara Province are primary data in the form of attributes related to the three dimensions to be studied, namely: (1) availability of feed ingredients; (2) production system, price and distribution system; and (3) human resources managers and breeders. Primary data comes from interviews with selected respondents, experts, and stakeholders as well as direct observations in the field. Determination of respondents based on the type of data collected by purposive random sampling technique, namely seven managers of the Bumbang Wetan feed bank, five heads of farmer groups in five villages of 1000 cattle in Pujut District, Central Lombok Regency, five agricultural extension workers who served in five villages of 1000 cattle, one veterinarian/veterinary medical officer, one Head of the Animal Husbandry Unit of Pujut District, one Head/official of the Livestock Service Office of Central Lombok Regency and one Head/officer of the Animal Husbandry and Animal Health Service of West Nusa Tenggara Province. Seven expert respondents were chosen in addition to having competence, experience, credibility, neutrality, and being willing to provide answers. The total number of respondents is 28 people

The data were analyzed through six stages, namely: (1) Determination of attributes that include six dimensions of sustainability. The number of attributes to be analyzed is 66 attributes, consisting of 10 availability of feed raw materials; 13 systems of production, pricing and distribution of products; and human resource managers and breeders; (2) assessment of each attribute on an ordinal scale based on the sustainability criteria of each dimension; (3) preparation of index and sustainability status of feed banks and their development both in multidimensional and in each dimension; (4) the stage of ordination; (5) a sensitivity analysis (leverage analysis) to determine the variables sensitive to sustainability; (6) Monte Carlo analysis to take into account the uncertainty aspect.

\section{RESULTS AND DISCUSSION}

\section{Dimensions of availability of feed ingredients}

Based on the results of the preparation of the sustainability index scale for the development of feed banks in support of the 1000 village cattle program on collective farmbased beef cattle farms in Pujut District, Central Lombok Regency, the sustainability index value for the dimensions of the availability of feed ingredients is 60.33 or is in the fairly sustainable category (Susilo, 2016), as shown in Figure 1.

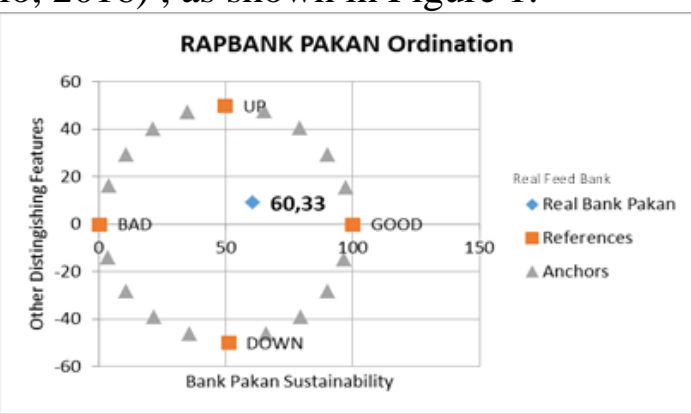

Figure 1. Sustainability index of the dimensions of the availability of feed ingredients 
There are 10 attributes studied on the dimensions of the availability of feed ingredients in the development of feed banks in supporting the 1000 village cattle program in Pujut District, Central Lombok Regency, West Nusa Tenggara Province, as shown in Figure 2. The results of the Leverage analysis in Figure 2 shows that of the 10 attributes studied, there are five most sensitive attributes that need to be improved for the sustainability of feed banks based on the root mean square (RMS) value, namely: (1) feed ingredients grown/ cultivated > $80 \%$; (2) the types of feed ingredients available in the rainy season are very large; (3) reduced feed ingredients in the dry season; (4) forage dries up in the dry season and (5) breeders have used concentrate. The greater the RMS value, the more sensitive the attribute in influencing the sustainability of feed bank development in the 1000 village beef cattle program based on collective cages (Figure 2).

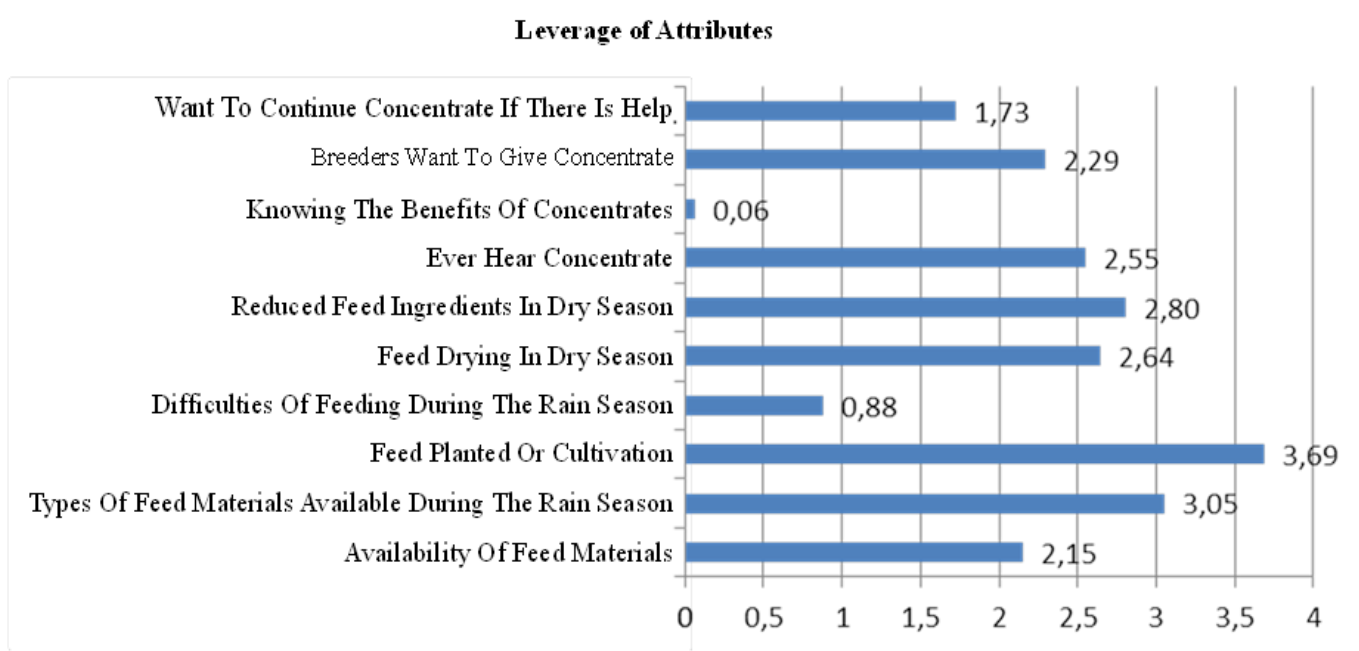

Root Mean Square Change in Ordination when Selected Attribute Removed (on Sustainability scale 0 to 100)

Figure 2. The Root Mean Square value for each attribute of the dimensions of the availability of feed ingredients based on Leverage analisis analysis

To see the effect of errors from the results of the ordinance of the sustainability of the feed bank, a Monte Carlo analysis was carried out which is a statistical simulation method to evaluate the effect of error or the effect of the error on the statistical process. The results of the Monte Carlo analysis on the dimensions of the availability of feed ingredients show that the points in the scatter plot are in the position of gathering in the middle. This means that the results of the ordinance points used in determining the sustainability status of the feed bank are quite stable so that errors can be overcome. According to (Kavanagh \& Pitcher, 2004), the error of ordination results is indicated by points that are spread out or separated from other sets of points in the scatter plot caused by: (1) the influence of attribute scoring errors caused by lack of information, misunderstanding of attributes or the way of making attribute scores. ; (2) the effect of variations in scoring due to different opinions or assessments by different researchers; (3) the stability of the MDS analysis process that is repeated (unstable anchor position); (4) data entry errors or missing data; and (5) the high value of "stress" analysis results. In detail, the results of the Monte Carlo ordination of the dimensions of the availability of feed ingredients are shown in the form of a scatter plot in

1. Dimensions of human resources for feed bank managers

Based on the results of the preparation of the sustainability index scale for the development of the feed bank in the 1000 village cattle program on the community cattle farms based on collective cages in Pujut District, Central Lombok Regency, the sustainability index value for the dimensions of human resources managing the feed bank is 48.76 or is in the less sustainable category (Susilo, 2016), as shown in Figure 4. 


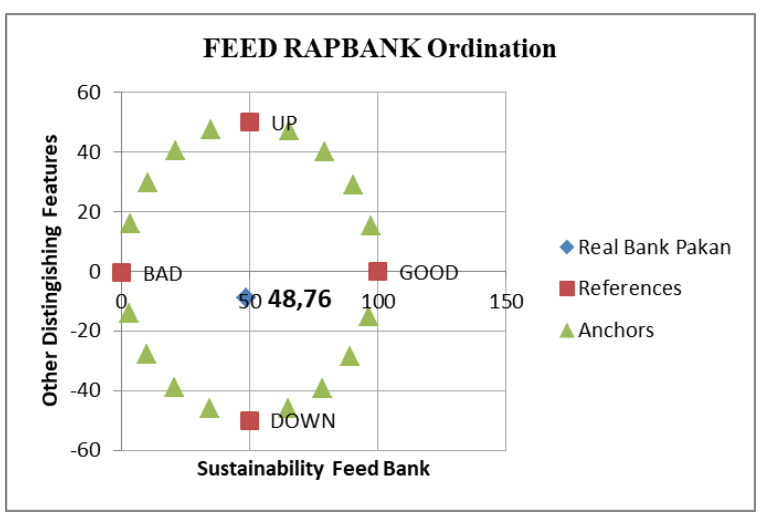

Figure 4. Sustainability index of the human resource dimensions of feed bank managers

There are 10 attributes studied in the human resource dimensions of feed bank managers in the development of feed banks in supporting the 1000 village cattle program in Pujut District, Central Lombok Regency, West Nusa Tenggara Province, as shown in Figure 5. The results of the Leverage analysis in Figure 5 show that out of 10 the attributes studied, there are five most sensitive attributes that need to be improved for the sustainability of the feed bank based on the root mean square (RMS) value, namely: (1) limited number of personnel; (2) knowledge of cooperation/partnership is less than optimal; (3) lack of administrative/financial knowledge; (4) lack of readiness to become a manager; (5) lack of business knowledge; and (6) feed products need to be tested first

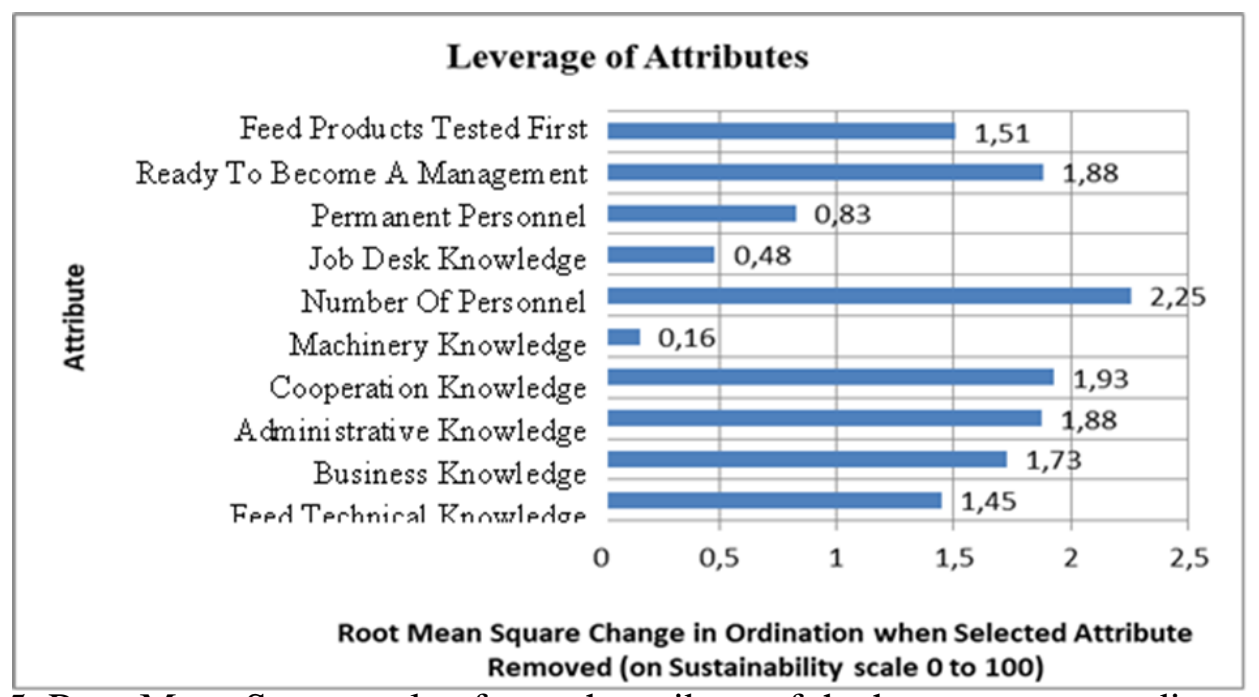

Figure 5. Root Mean Square value for each attribute of the human resource dimension of feed bank manager

To see the effect of errors from the results of the ordinance of the sustainability of the feed bank, a Monte Carlo analysis was carried out which is a statistical simulation method to evaluate the effect of error or the effect of error on the statistical process. The results of the Monte Carlo analysis on the human resource dimension of the feed bank manager show that the points in the scatter plot are in a clustered position in the middle. This means that the results of the ordinance points used in determining the sustainability status of the feed bank are quite stable, so that errors can be overcome. According to (Kavanagh \& Pitcher, 2004) the error of ordination results is indicated by points that are spread out or separated from other sets of points in the scatter plot caused by: (1) the influence of attribute scoring errors caused by lack of information, misunderstanding of attributes or the way of making attribute scores. ; (2) the effect of variations in scoring due to different opinions or assessments by different researchers; (3) the stability of the MDS analysis process that is repeated (unstable anchor 
position); (4) data entry errors or missing data; and (5) the high value of "stress" analysis results. In detail, the results of the Monte Carlo ordinance of the human resource dimensions of feed bank managers are shown in the form of a scatter plot in Figure 6

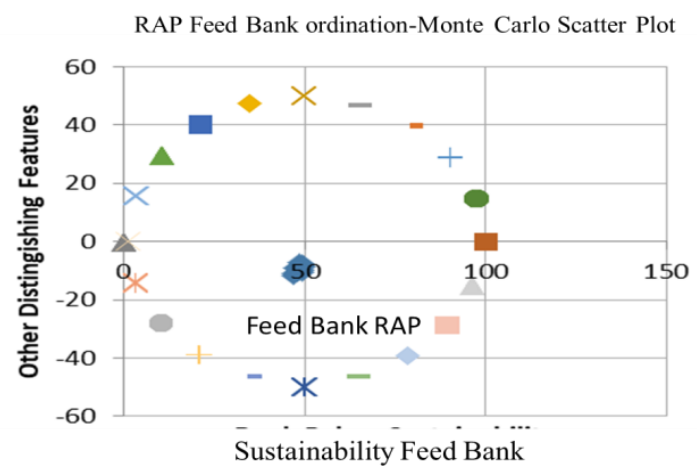

Figure 6. Scatter plot based on Monte Carlo analisis analysis

\section{Dimensions of production, pricing and distribution systems}

Based on the results of the preparation of the sustainability index scale for the development of the feed bank in the 1000 village cattle program on beef cattle farms based on collective cages in Pujut District, Central Lombok Regency, the sustainability index value for the dimensions of the production, price and distribution system was 44.64 or was in the less sustainable category (Susilo, 2016), as shown in Figure 7.

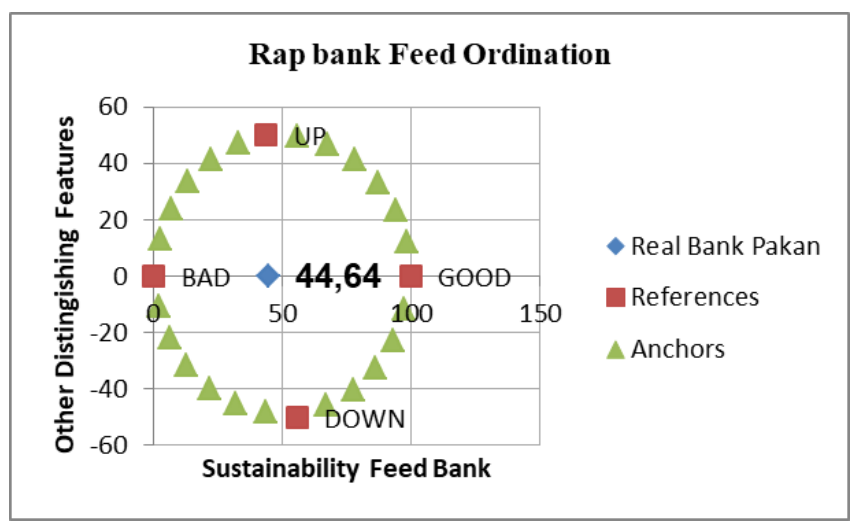

Figure 7. Sustainability index of the dimensions of the production system, prices and distribution of feed banks

There are 13 attributes studied in the dimensions of the production, price and distribution system in the development of feed banks in support of the 1000 village cattle program in Pujut District, Central Lombok Regency, West Nusa Tenggara Province, as shown in Figure 8. The results of the Leverage analysis in Figure 8 show that from 13 the attributes studied, there are seven most sensitive attributes that need to be improved for the sustainability of the feed bank based on the root mean square (RMS) value, namely: (1) production planning has not been made; (2) the price of the product $/ \mathrm{kg}$ according to the breeder is expensive; (3) product demand is not optimal; (4) no potential product sales partners; (5) the supply of raw materials is limited in the dry season, (6) the price of raw materials for feed is expensive in the dry season; and (7) the products made have not been sold/used yet 


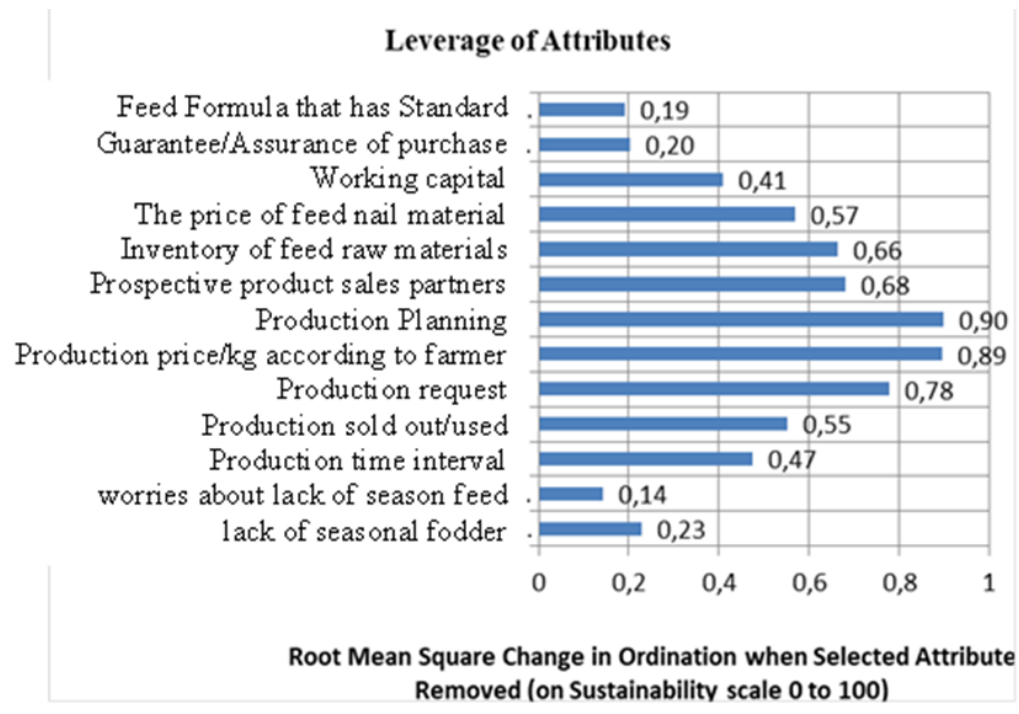

Figure 8. Root Mean Square value for each attribute of the dimensions of the production system, price and distribution of the feed bank

To see the effect of errors from the results of the ordinance of the sustainability of the feed bank, a Monte Carlo analysis was carried out which is a statistical simulation method to evaluate the effect of error or the effect of error on the statistical process. The results of the Monte Carlo analysis on the dimensions of the production, price and distribution system show that the points in the scatter plot are in a clustered position in the middle. This means that the results of the ordinance points used in determining the sustainability status of the feed bank are quite stable, so that errors can be overcome. According to (Kavanagh \& Pitcher, 2004) the error of ordination results is indicated by points that are spread out or separated from other sets of points in the scatter plot caused by: (1) the influence of attribute scoring errors caused by lack of information, misunderstanding of attributes or the way of making attribute scores. ; (2) the effect of variations in scoring due to different opinions or assessments by different researchers; (3) the stability of the MDS analysis process that is repeated (unstable anchor position); (4) data entry errors or missing data; and (5) the high value of "stress" analysis results. In detail, the results of the Monte Carlo ordination of the dimensions of the production system, price and distribution of the feed bank are shown in the form of a scatter plot in Figure 9.

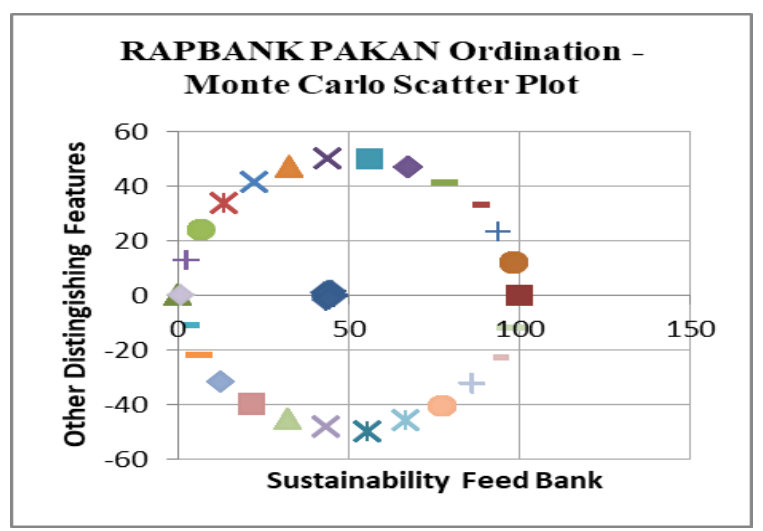

Figure 9. Scatter plot based on Monte Carlo analisis analysis

\section{The value of stress and coefficient of determination $(\mathrm{R} 2)$ is multidimensional}

The stress value and the coefficient of determination are used to see the accuracy of the results of the sustainability index values of the six dimensions studied, so that they can be justified scientifically. The stress value is defined as a measure to see whether the accuracy of 
the results obtained is close to the original data (goodness of fit), if the stress value is getting closer to zero, it indicates that the resulting data can be trusted. The stress values and the coefficient of determination on each dimension of the sustainability status of the feed bank in Pujut District, Central Lombok Regency are shown in Table 2

Table 2. Stress value and coefficient of determination (R2) of the three dimensions of feed bank development on beef cattle farms based on collective cages in 1000 cattle villages in Pujut District, Central Lombok Regency

\begin{tabular}{lcccc}
\hline \multicolumn{1}{c}{ Dimension } & Stress value & $\%$ & $\begin{array}{c}\text { Coefficient of } \\
\text { determination } \\
(\mathrm{R} 2)\end{array}$ & $\%$ \\
\hline $\begin{array}{l}\text { Availability of feed ingredients } \\
\begin{array}{l}\text { Human resources for feed bank } \\
\text { managers }\end{array}\end{array}$ & 0.141208 & 14.12 & 0.950629 & 95.06 \\
$\begin{array}{l}\text { Production, pricing and distribution } \\
\text { systems }\end{array}$ & 0.150141 & 15.01 & 0.947333 & 94.73 \\
\hline
\end{tabular}

Based on Table 2, it appears that the stress values of the three dimensions studied are between $0.141208-0.150104$ or $14-15 \%$ with a coefficient of determination 0.947333 0.950629 or $94-95 \%$. Based on this data, the three dimensions studied in the development of the feed bank are stated to be quite accurate so that they provide good analytical results and can be scientifically justified. This is in accordance with the research results of (Fauzi \& Suzy Anna, 2005) in the Rapfish model and (Mashur, 2017; Mashur et al., 2021) ) in the Rapbeefcattle smallholder (RAPBCS) that a good number is indicated by the stress value < 0.25 (25\%), while the coefficient of determination (R2) $80 \%$ or 100\% (Hartono, 2005).

2. Feed bank multidimensional sustainability status

Based on Table 3, it appears that from the three dimensions studied, it appears that only the availability of feed ingredients has a moderately sustainable category, while the other two dimensions have a less sustainable category. This means that the available feedstuffs are quite abundant in the rainy season or at harvest, but reduced in the dry season. The results of this study are in accordance with the results of (Gharehyakheh \& Sadeghiamirshahidi, 2018; Mashur, 2017), the main problem faced by smallholder beef cattle farms in West Nusa Tenggara is the limited supply of feed, especially during the long dry season. If the two dimensions that are included in the less sustainable category are not made efforts to improve, improve and improve the sensitive attributes that affect the sustainability of the feed bank, the existence of the feed bank in the case study of the Bumbang Wetan Feed Bank in Mertak Village, Pujut District, Central Lombok Province West Nusa Tenggara, which is used as a pilot model for feed banks in Indonesia in supporting 1000 cattle villages to achieve meat self-sufficiency, is in danger of not being able to function optimally, and will even files. Therefore, various coaching strategies and capacity building are needed in their development, so that they can be more optimal in supporting the 1000 cow village program

Table 3. Formulation of the three dimensions of the sustainability index scale of feed bank development

\begin{tabular}{lcc}
\hline \multicolumn{1}{c}{ Dimension } & Sustainability index & Category \\
\hline Availability of feed ingredients & 60,33 & enough \\
Human resources for feed bank managers & 48,76 & not enough \\
Production, pricing and distribution systems & 44,64 & not enough \\
\hline
\end{tabular}

Index standard: $<25$ = bad, 25-50 = less; 51-75= enough; >75 = good (Soesilo, 2013)

Determining the value of the sustainability index in a multidimensional manner is an illustration of the sustainability of the feed bank in supporting the 1000 village cattle program in Pujut District, Central Lombok Regency. Multidimensional value is obtained by 
multiplying the index value between dimensions by the weights between dimensions based on expert opinion. According to (Mashur et al., 2021) in looking at the multidimensional value of the six dimensions it cannot be done with an average, but must be done with a pair wise comparison test obtained from expert assessments in the field of smallholder livestock (availability of feed ingredients, human resource management). feed bank and production system, price and distribution), so that the weights of each dimension are obtained, as shown in Table 4 below.

Table 4. Multidimensional index value of feed bank sustainability status in supporting the 1000 village cattle program in Pujut District, Central Lombok

\begin{tabular}{lccc}
\hline \multicolumn{1}{c}{ Dimension } & $\begin{array}{c}\text { Weight } \\
\text { value } \\
(\%)\end{array}$ & $\begin{array}{c}\text { Sustainability } \\
\text { Index Value }\end{array}$ & $\begin{array}{c}\text { Weighted Result } \\
\text { Index Value }\end{array}$ \\
\hline Availability of feed ingredients & 28.58 & 60,33 & 17.24 \\
Human resources for feed bank managers & 35.71 & 48,76 & 17.41 \\
Production, pricing and distribution systems & 35.71 & 44,64 & 15.94 \\
\hline Total & 100 & & $\mathbf{5 0 , 5 9}$
\end{tabular}

Based on the results of the multidimensional analysis of the sustainability of the feed bank in supporting the 1000 village cattle program in Pujut District, Central Lombok Regency, the combined value of the three dimensions was 59.59. This figure indicates the category of less sustainable, in accordance with the sustainability standards of (Susilo, 2016). The combined sustainability index value of the three dimensions of the feed bank is shown in the form of a kite diagram in Figure 10

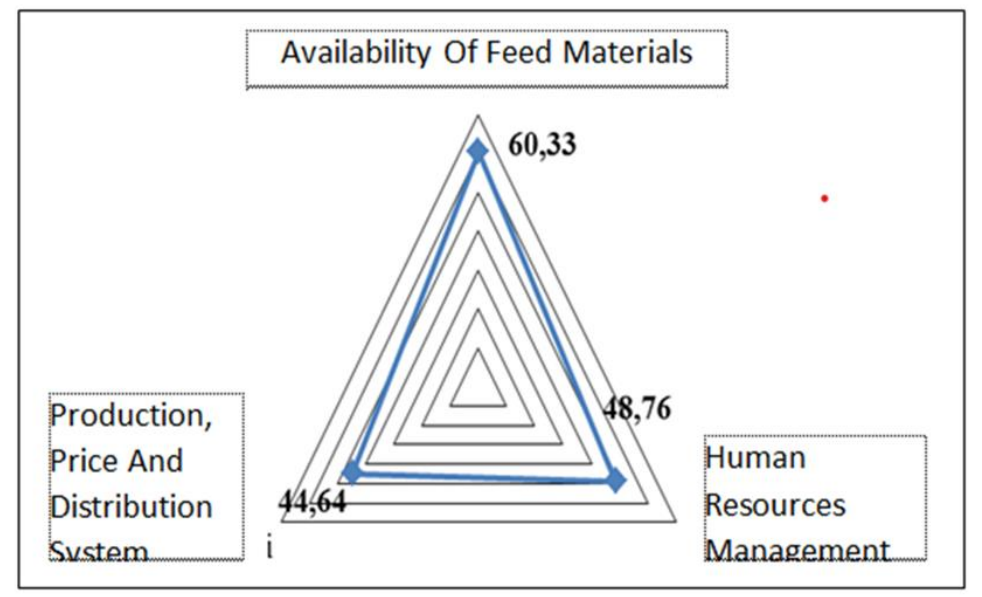

Figure 10. Kite diagram of the combined sustainability index value of the three dimensions of the feed bank

If no improvements are made to the sensitive attributes that affect the sustainability of the feed bank in each dimension, the feed bank program cannot run optimally or cannot continue, it could even threaten to fail in supporting the 1000 cattle village program. This will have an impact on beef self-sufficiency efforts

Table 5. Attributes sensitive to each dimension based on RMS values and expert assessments on the development of feed banks in support of the 1000 village cattle program in Pujut District, Central Lombok

\begin{tabular}{lllcc}
\hline \multicolumn{1}{c}{ Dimension } & \multicolumn{1}{c}{ Atribut sensitive } & RMS* & $\begin{array}{c}\text { Expert } \\
\text { Rating }\end{array}$ \\
\hline $\begin{array}{l}\text { Availability } \\
\text { of feed }\end{array}$ & $\bullet$ & Feed ingredients grown/cultivated > 80\%; & 3.69 & 4 \\
ingredients & $\bullet$ & There are many types of feed ingredients available & 3.05 & 6 \\
& in the rainy season; & 2.80 & 5 \\
& $-\quad$ Feed ingredients are reduced in the dry season; & 2.64 & 3 \\
& $-\quad$ Forage dries up in the dry season & 2.55 & 2 \\
& $\bullet \quad$ Breeders have used concentrate & & \\
\hline
\end{tabular}




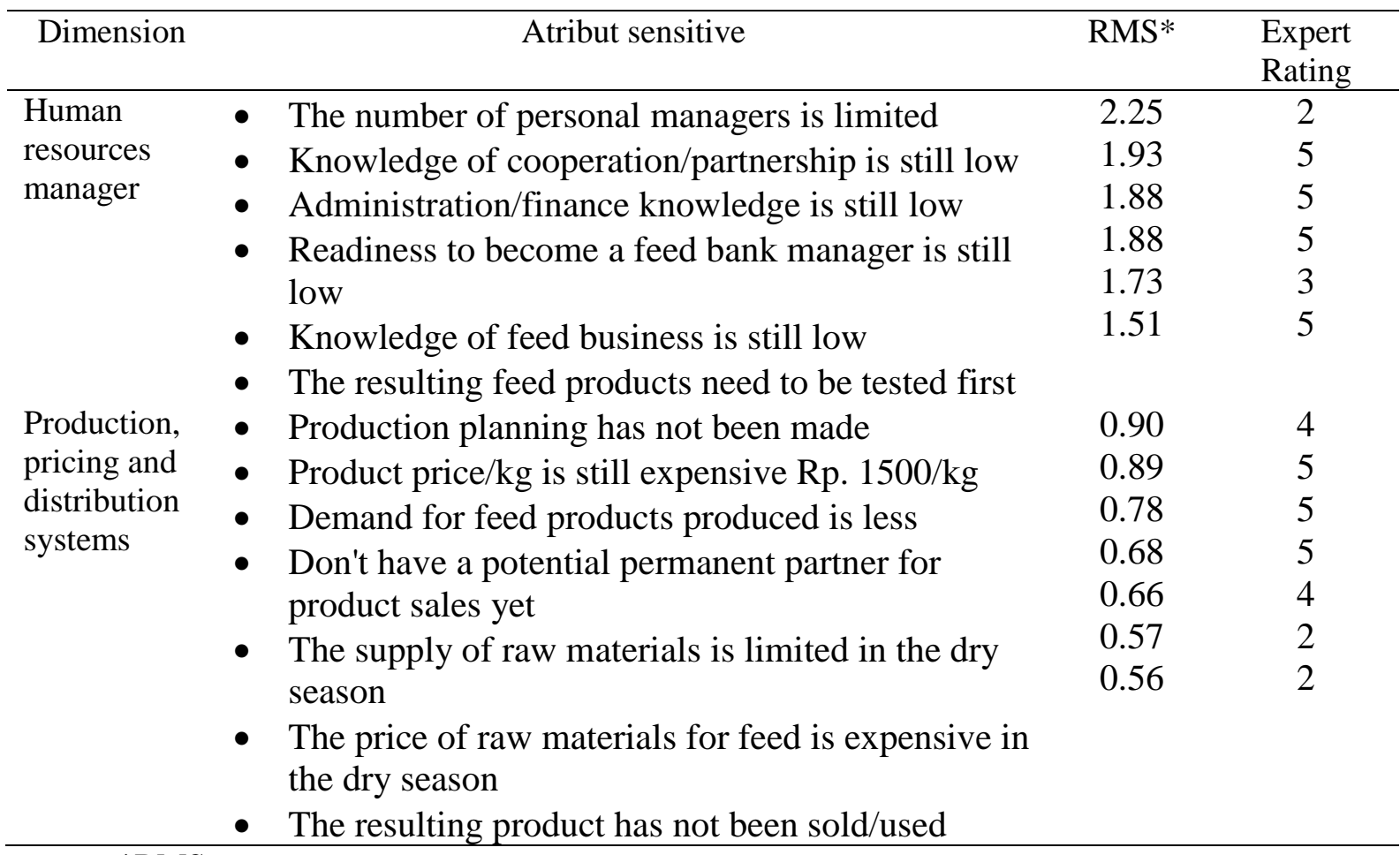

$* \mathrm{RMS}=$ root mean square

Furthermore, from the 18 sensitive attributes, a prospective assessment was carried out by experts and 12 key success factors were determined, namely: (1) Feed ingredients grown/cultivated $>80 \%$; (2) The types of feed ingredients available in the rainy season are very large; (3) Feed ingredients are reduced in the dry season, (4) Knowledge of partnership cooperation is still low, (5) Knowledge of financial administration is still low, (6) Readiness to become a feed bank manager is still low, (7) The feed products produced need to be tested first , (8) Production planning has not been made, (9) Product price/kg is still expensive Rp. $1500 / \mathrm{kg}$, (10) There is less demand for feed products, (11) Do not have a potential permanent partner for product sales and (12) Inventory of materials limited standard of dry season.

\section{CONCLUSION}

Based on the results of the study, it can be concluded that the sustainability status of the feed bank in the case study of the Bumbang Wetan Feed Bank in Mertak Village, Pujut District, Central Lombok Regency, West Nusa Tenggara Province is multidimensional with the three dimensions studied being in the less sustainable category in supporting the 1000 village cattle program in Pujut District. Central Lombok Regency, West Nusa Tenggara Province

\section{RECOMMENDATION}

Based on the results of this study, it is recommended to make improvements to the 12 key success factors based on sensitive attributes and expert judges, so that the sustainability status of the feed bank can be improved from the less sustainable category to quite sustainable even good..

\section{ACKNOWLEDGMENT}

I would like to express my gratitude to: (1) the Chairperson of the Mataram IKIP Foundation and the Chancellor of the Mandalika Education University who have provided funds for Undikma's internal research in 2021; (2) Head of LPPM Mandalika University of Education who has approved this research; (3) The Dean of the Faculty of Veterinary Medicine, University of Mandalika Education who has provided research recommendations and (4) students of the Faculty of Veterinary Medicine, University of Mandalika Education 
who are taking Feed Science and Nutrition courses even semester 2021 who have helped collect data

\section{REFERENCES}

Fauzi, A. \& Suzy Anna. (2005). Pemodelan sumber daya perikanan dan kelautan untuk analisis kebijakan. PT. Gramedia Pustaka Utama.

George, D., \& Mallery, P. (2014). IBM statistics 21 step by step: A simple guide and reference (Thirteenth edition). Pearson.

Gharehyakheh, A., \& Sadeghiamirshahidi, N. (2018). A Sustainable Approach in Food Bank Logistics.

Hartono, T. T. (2005). Pengembangan Teknik Rapid Appraisal for Fisheries (RAPFISH) untuk Penentuan Indikator Kinerja Perikanan Tangkap Berkelanjutan di Indonesia. 12.

Herman. (2020). Program 1.000 Desa Sapi Wujudkan Swasembada Daging. beritasatu.com. https://www.beritasatu.com/ekonomi/668299/program-1000-desa-sapi-wujudkanswasembada-daging

Kavanagh, P., \& Pitcher, T. J. (2004). Implementing Microsoft Excel software for Rapfish: A technique for the rapid appraisal of fisheries status. https://doi.org/10.14288/1.0074801

Mashur, M. (2017). The Main Problems Of Smallholders Cattle Farming In Facing The Asean Economic Community In West Nusa Tenggara. Proceedings The 5 Th International Seminar Of Animal Nutrition And Feed Sciences.

Mashur, M., Agustin, A. L. D., Ningtyas, N. S. I., Multazam, A., \& Ningsih, M. (2020). Gelar Teknologi Pengolahan Kotoran Sapi dan Limbah Rumah Tangga Menjadi Eksmecat untuk Meningkatkan Pendapatan Masyarakat. Sasambo: Jurnal Abdimas (Journal of Community Service), 2(3), 86. https://doi.org/10.36312/sasambo.v2i3.279

Mashur, M., Oktaviana, D., Ilyas, M. A., Hunaepi, H., \& Setiawan, S. (2021). Diseminasi Teknologi Pembuatan Haylage Plus untuk Mengatasi Kesulitan Pakan Sapi Potong pada Musim Kemarau. Lumbung Inovasi: Jurnal Pengabdian Kepada Masyarakat, 6(1), 22-30. https://doi.org/10.36312/linov.v6i1.486

Nuryadin, R. (2015). Analisis Keberlanjutan Pengembangan Kawasan Pesisir Berbasis Rumput Laut Di Kabupaten Sumbawa Barat. [Thesis, Bogor Agricultural University (IPB)]. http://repository.ipb.ac.id/handle/123456789/79335

Ramadhan, D. R., Nindyantoro, N., \& Suyitman, S. (2014). Status Keberlanjutan Wilayah Peternakan Sapi Potong untuk Pengembangan Kawasan Agropolitan di Kabupaten Bondowoso. Jurnal Peternakan Indonesia (Indonesian Journal of Animal Science), 16(2), 78-88. https://doi.org/10.25077/jpi.16.2.78-88.2014

Susilo, S. B. (2016, October 19). Keberlanjutan Pembangunan Pulau-pulau Kecil Studi Kasus Kelurahan Pulau Panggang dan Pulau Pari, Kepulauan Seribu, Dki Jakarta| Sosial dan Ekonomi | LIPI. http://www.pksdmo.lipi.go.id/HASILPENELITIAN/Sosial-dan-Ekonomi_2650_52/Keberlanjutan-Pembangunan-Pulaupulau-Kecil-Studi-Kasus-Kelurahan-Pulau-Panggang-dan-Pulau-Pari-KepulauanSeribu-Dki-Jakarta.html

Suyitman, S., Sutjahjo, S. H., \& Djulardi, A. (2012). Status Keberlanjutan Wilayah Berbasis Peternakan Sapi Potong Terpadu di Kabupaten Lima Puluh Kota - Sumatera Barat. Jurnal Peternakan Indonesia (Indonesian Journal of Animal Science), 14(1), 318. https://doi.org/10.25077/jpi.14.1.318-336.2012 